
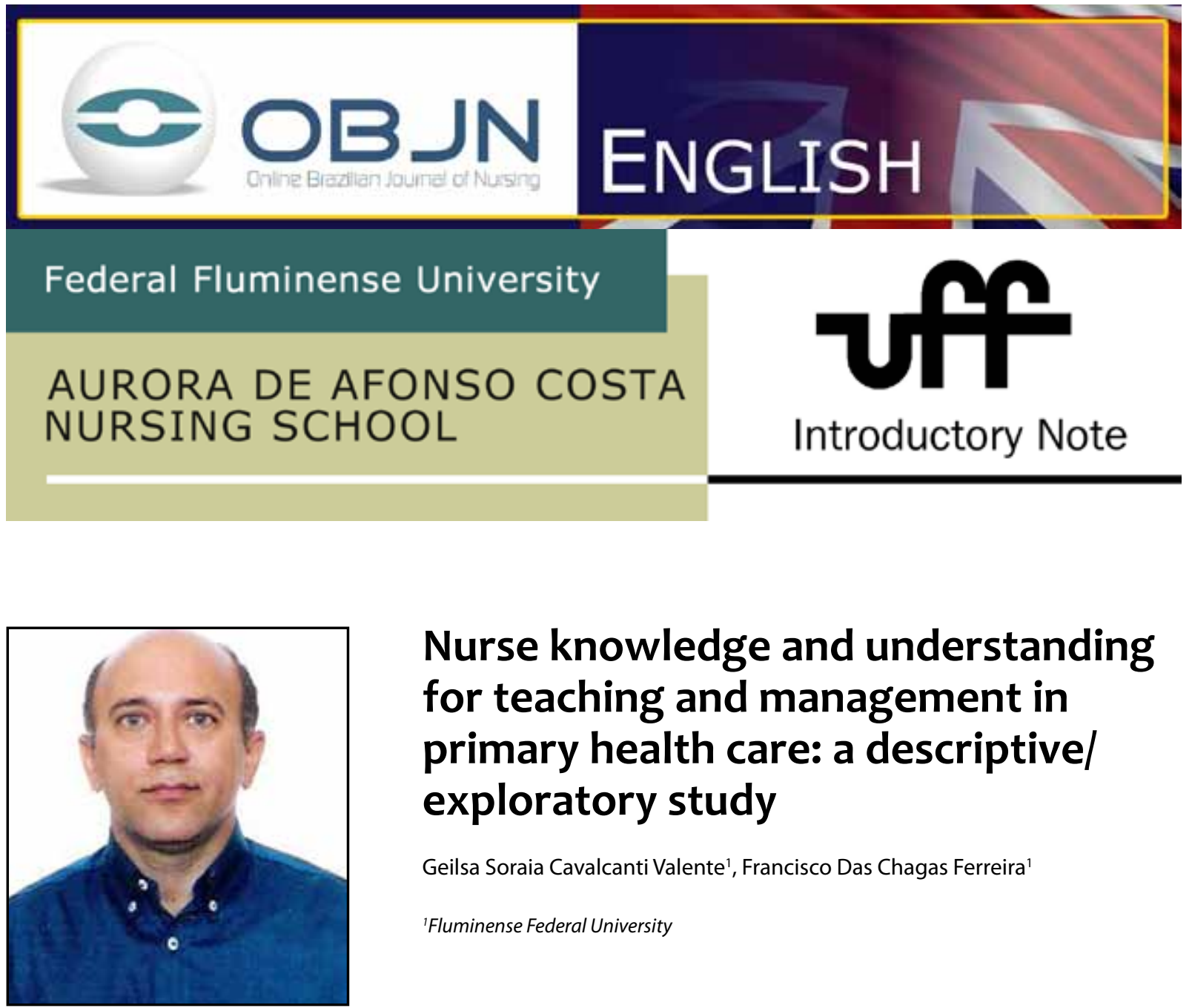

\title{
Nurse knowledge and understanding for teaching and management in primary health care: a descriptive/ exploratory study
}

Geilsa Soraia Cavalcanti Valente' ${ }^{1}$ Francisco Das Chagas Ferreira'

'Fluminense Federal University

\section{ABSTRACT}

This is dissertation project in progress for a Masters Course in Health Care Teaching at Fluminense Federal University (UFF).

Aims: To identify the nursing knowledge and skills that need to be developed for management and preceptorship in a primary health care system; to analyze and discuss the implications for pedagogical practice for nursing preceptors during their training; to describe the tasks carried out by nurses while managing and preceptorship students in a preceptors health care unit; and to develop educational technology for permanent pedagogical nursing training.

Method: qualitative, exploratory and descriptive research to take place at a primary health care unit in the municipality of Niteroi, Rio de Janeiro State. The research subjects will be nurse preceptors. The data will be gathered from August to December 2013, by means of semi-structured interviews and a thematic analysis of the content.

Descriptors: Education, Nursing; Preceptorship; Management; Health Services Administration; Primary Health Care. 


\section{SITUATION PROBLEM AND ITS SIGNIFICANCE}

Historically, public health policies had undergone an evolutionary process that has culminated in the creation of the Unified Health System (SUS), a fruit of the implementation of the 1988 Constitution. This model involved a paradigm shift from a curative health model to a model based on the social production of health in its broader concept. The regulation of SUS through the Organic Law 8.080/90 and $8.142 / 90$, had implications in the field of health care training. For education, an important event was the enactment of the law relating to Guidelines and Bases of National Education (LDBEN 9.394/96). This, in turn, led to the drafting of the National Curriculum Guidelines (DCNs) for degree courses in Nursing, in order to organize the critical and reflective training of future professionals. The dialectical relationship between education, health and nursing training, motivated by social practices, is the tripod that shapes nursing education ${ }^{(1)}$.

It is clearly the responsibility of higher education institutions to train competent professionals. To do so, such institutions need field internships for students to allow them be involved in practice. One such internship takes place in the primary health care network.

It is precisely in the context of the implementation of the supervised internships that the preceptor's role emerges in nursing undergraduate courses. Generally, in this context, nurses working in primary health care management programs are required to exercise a double role in their daily practice since, during their management activities, they also perform the important task of preceptorship. As expected, the NHS should contribute as a practical field for education, and according to specific rules.

The mediating role of the teacher in the construction and enhancement of learning that is reconstructed in practice, is essential to nursing education. The role of the teacher is vital as he/she enables encounters between the students and institution's clients. Thus, one notices that when there is SUS (NHS) professionals' involvement in activities where they supervise and guide students, "...this involvement [...] requires an increment of training/educational acculturation that goes beyond the technical functions they are assigned to"(2).

Thus, it is clear the preceptor needs support to improve the didactic and pedagogic training for which s/he is responsible, in order to implement and develop their skills in such a way as to improve the training of other professionals.

\section{GUIDING QUESTIONS}

What skills and knowledge must nurse educators acquire in order to work with management and preceptorship in the primary health care network?

\section{AIMS}

To describe the actions carried out by nurse educators while teaching students and working with management in the primary health care network;

To identify the knowledge and skills nurse educators need to acquire in order to improve the management and preceptorship of students in the primary health care network;

To analyze and discuss the pedagogical and management implications for nurse educators during their own continual learning and; to develop educational technology for permanent pedagogical training of student preceptorss in the primary health care network, based on 
knowledge and skills, thus providing with the development and articulation of theoretical and practical knowledge associated with teaching and management.

\section{METHOD}

This research is in line with pedagogical research in health, and can be considered qualitative research due to its characteristics that enable the description of events associated with the investigated subjects.

The objective will be exploratory since it involves interviews with people who have first-hand experience with the problems under consideration, as well as the analysis of the studied samples in such a way as to facilitate understanding.

Furthermore, it is descriptive in nature, as it will be used as a research tool, involving semi-structured interviews that combine open and closed questions where the respondent has the opportunity to discuss the theme without pre-written answers or conditions imposed by the researcher.

The scenario will be a regional polyclinic, a primary health care unit of SUS/Niterói. The subjects are all nurses working in program management and student teaching, 6 professionals in total. Data will be collected from August to December 2013 which will then undergo thematic content analysis.

The project has been submitted to the Ethics Committee of the University Hospital
Antonio Pedro at Fluminense Federal University (HUAP/UFF). The subjects involved in the research will be consulted in advance, and will agree to participate by signing an Informed Consent form. Permission for data collection was granted by the Board of Directors at the polyclinic to be studied.

\section{REFERENCES}

1. Saraiva R, Rosas A, Rodrigues B, Domingos A, Cardoso M, Valente GSC. Intentional action of nursing education of consultation: phenomenological study. Online braz j nurs [Internet]. 2012 [Cited 2012 July 1]; 11(1): 157-66. Available from: http://www.objnursing.uff.br/index.php/ nursing/article/view/3518

2. Resck ZMR, Gomes ELR. A formação e a prática gerencial do enfermeiro: caminhos para a práxis transformadora. Rev latinoam enfermagem [Internet]. 2008 Sept [cited 2013 Mar 02];16(1):71-7. Available from: http://www.scielo.br/pdf/rlae/ v16n1/pt_11.pdf

Project information: This is a Dissertation Project for the Masters Course in Health Care Education at UFF.

This project has been submitted to the Ethics Committee of the University Hospital Antonio Pedro at Fluminense Federal University (HUAP / UFF), and is awaiting approval.

Mentor: Geilsa Soraia Cavalcanti Valente

Received: 27/05/2013

Revised: 20/06/2013

Approved: 20/06/2013 